PART II. PHYSICAL ACTIVITY OF SOCIAL AND PROFESSIONAL GROUPS

DZIAŁ II. AKTYWNOŚĆ FIZYCZNA GRUP SPOŁECZNYCH I ZAWODOWYCH

\title{
CAN BEHAVIORAL INTERVENTIONS INCREASE PHYSICAL ACTIVITY IN YOUTH WITH CEREBRAL PALSY? A SCOPING REVIEW
}

\section{CZY INTERWENCJE BEHAWIORALNE MOGĄ ZWIĘKSZYĆ AKTYWNOŚĆ FIZYCZNĄ MLODYCH OSÓB Z MÓZGOWYM PORAŻENIEM DZIECIĘCYM? PRZEGLĄD ZAKRESU DZIAŁAŃ}

\author{
Tigran Petrosyan $^{1(\mathrm{~A}, \mathrm{C}, \mathrm{D}, \mathrm{E})}$, Hasmik Mkrtchyan ${ }^{1(\mathrm{~B}, \mathrm{C}, \mathrm{D}, \mathrm{F})}$, Naira Martirosyan $^{2(\mathrm{C}, \mathrm{D}, \mathrm{E}, \mathrm{F})}$ \\ ${ }^{1}$ Physical Rehabilitation Department, Armenian State Institute of Physical Culture and Sports, Yerevan, Armenia \\ ${ }^{2}$ Yerevan Special School for Children with Motor Disability, Yerevan, Armenia
}

Authors' contribution Wkład autorów:

A. Study design/planning zaplanowanie badań

B. Data collection/entry zebranie danych

C. Data analysis/statistics dane - analiza i statystyki D. Data interpretation interpretacja danych E. Preparation of manuscript przygotowanie artykułu F. Literature analysis/search wyszukiwanie i analiza literatury G. Funds collection zebranie funduszy

\section{Summary}

The primary goal of adaptive physical and special education is to increase the participation of individuals with special motor needs in educational and social activities. Current behavior modification and motivation techniques are based on descriptive explanations of physical activity behaviors and exercises provided by special educators to patients and parents; however, the efficacy of such techniques is largely unknown. The main purpose of this review was to determine how effective different special education techniques and behavior change interventions are for different domains of physical activity for patients with cerebral palsy spastic motor type. A scoping review of scientific/medical databases was conducted to identify relevant studies matched the pre-defined inclusion and exclusion criteria. Four studies were selected $(n=173)$ implementing behavioral interventions across internet-based and in-person settings. Three of these studies were randomized controlled trials with pre-post differences in physical activity observed in youth with cerebral palsy following behavioral intervention, although improvements were not statistically different from controls. This scoping review collectively demonstrates that design and implementation of behavioral change interventions lead to improvements of specific motor skills and highlights the need for ongoing research in children and adults with special motor needs.

Keywords: motor disability, behavioral change, special education, physical activity, motivation

\section{Streszczenie}

Podstawowym celem adaptacyjnej edukacji fizycznej i specjalnej jest zwiększenie udziału osób ze specjalnymi potrzebami ruchowymi w działaniach edukacyjnych i społecznych. Obecnie techniki modyfikujace zachowania i motywację opierają się na wyjaśnieniach, jakich pedagodzy specjalni udzielają pacjentom i rodzicom, opisując ćwiczenia i zachowania związane z aktywnością fizyczną, niemniej jednak skuteczność tych technik jest nieznana. Podstawowym celem pracy jest określenie skuteczności różnych technik edukacji specjalnej i interwencji w zakresie zmiany zachowań w różnych domenach aktywności fizycznej pacjentów z mózgowym porażeniem dziecięcym typu spastycznego. Przeprowadzono przegląd naukowych/medycznych baz danych w poszukiwaniu stosownych badań, które odpowiadały wcześniej zdefiniowanym kryteriom włączenia i wyłączenia. W czterech wybranych badaniach $(\mathrm{n}=173)$ zastosowano interwencje behawioralne przeprowadzone za pomocą Internetu oraz osobiście. Trzy z badań były randomizowanymi kontrolowanymi badaniami, w których zaobserwowano różnice $\mathrm{w}$ aktywności fizycznej młodzieży z mózgowym porażeniem dziecięcym przed i po przeprowadzeniu interwencji behawioralnej, niemniej jednak stopień poprawy nie różnił się statystycznie od grupy kontrolnej. Przegląd wykazał, że projektowanie i wdrażanie zmian behawioralnych prowadzi do poprawy określonych umiejętności motorycznych, a także, że istnieje zapotrzebowanie na nowe badania dotyczące dzieci i dorosłych ze specjalnymi potrzebami ruchowymi.

Słowa kluczowe: niepełnosprawność ruchowa, zmiana behawioralna, edukacja specjalna, aktywność fizyczna, motywacja
Tables: 1
Figures: 1

References: 42

Submitted: 2021 Sep 4

Accepted: 2021 Oct 18

Petrosyan T, Mkrtchyan H, Martirosyan N. Can behavioral interventions increase physical activity in youth with cerebral palsy? A scoping review. Health Prob Civil. 2021; 15(4): 315-322. https://doi.org/10.5114/hpc.2021.110112

Address for correspondence / Adres korespondencyjny: Tigran Petrosyan, Physical Rehabilitation Department, Armenian State Institute of Physical Culture and Sports, 11 Alek Manukyan Street, 0070 Yerevan, Armenia, e-mail: tigran.petrosyan@sportedu.am, phone: +374 10556281

ORCID: Tigran Petrosyan https://orcid.org/0000-0002-5517-8856, Hasmik Mkrtchyan https://orcid.org/0000-0002-9495-3173

Copyright: (C) Pope John Paul II State School of Higher Education in Biała Podlaska, Tigran Petrosyan, Hasmik Mkrtchyan, Naira Martirosyan. This is an Open Access journal, all articles are distributed under the terms of the Creative Commons Attribution-NonCommercial-ShareAlike 4.0 International (CC BY-NC-SA 4.0) License (http://creativecommons.org/licenses/by-nc-sa/4.0/), allowing third parties to copy and redistribute the material in any medium or format and to remix, transform, and build upon the material, provided the original work is properly cited and states its license. 


\section{Introduction}

Physical activity (i.e., any body movement that uses energy) can occur at different intensities and for varying lengths of time [1,2]. Habitual physical activity is a particular sub-type of movement performed while carrying out usual daily living activities (e.g., lifting a book or box, walking across a room) [3]. Individuals with special motor needs have lower levels of habitual physical activity compared to healthy individuals $[4,5]$, although despite having different overall levels of habitual physical activity, ambulant and non-ambulant individuals with special motor needs experience similar rates of community-based physical activity [6,7]. A broad range of physical and neurological disorders present with special motor needs, of which cerebral palsy is the most commonly diagnosed amongst children and adolescents. The prevalence of cerebral palsy (CP) has been estimated 2.1 in 1000 [8]. Traditionally classified based on patients' motor manifestations, the majority (65\%) of patients with cerebral palsy are diagnosed with the spastic type [9], although other significant cognitive, sensory, and/or behavioral deficits may also be present as a result of neurological trauma [9].

Children with cerebral palsy and other neurological conditions have lower levels of physical activity on the weekends and higher activity scores on weekdays [10], explained by the presence of structured physical activity sessions throughout the week. Most children with motor disabilities participate in 2-3 structured physical education classes each week that are aided and controlled by an adaptive physical education instructor [10-13]. Participation in this type of structured physical activity requires a limited number of standard motor skills and application within a restricted range of environments. Alternatively, unaided and/or unstructured leisure activities pose completely different challenges, resulting in greater difficulties and lower rates of involvement, intensity, and enjoyment for children and adolescents with motor disabilities. Many social and daily living activities (e.g., going to the movies, vacations, birthday parties) with family, friends, peers, or community members can even require new or complex motor skills that are difficult for individuals with special motor needs to execute (e.g., going down a small flight of stairs, swimming, opening gifts) which can generate physical and psychological barriers to their participation. Family members' fears of their disabled child being injured and negative or stigmatizing social attitudes and beliefs can also serve as barriers to youth with special motor needs participating in unstructured recreational and leisure activities [14].

Within the scope of adaptive special education, the primary goal is to increase disabled individuals' participation in educational, recreational, and social activities. In this context, specialists refer to participation not only in educational, classroom-based environments, but also within the context of social integration and inclusion of individuals with different special motor needs and histories [15-17]. Although only 78\% of disabled individuals participate in inclusive leisure activities [18], participation in diverse and multifaceted groups has been shown to facilitate the process of inclusion, as well as children's safety and general well-being with their family members, cohorts and friends, and society at large [19,20]. In particular, participating in leisure activities is associated with enhanced elaboration of different social (e.g., sports, outdoor pursuits, arts and crafts, outings, electronic activities, music, and dance) and motor skills (e.g., majority of the manipulative skills) that could not be achieved in other, more restricted contexts [21], supporting the potential for adding leisure activities to the overall special intervention routine in favor of improving health outcomes for individuals with special motor needs.

Currently, rehabilitation interventions for children and adolescents with special motor needs usually target outcomes that are essential to participation in the family or educational environment and include task-specific exercise therapy sessions targeting key activities of daily living (e.g., grooming, dressing, toileting, ambulating, and eating). In fact, a substantial body of literature in this domain provides evidence-based recommendations for physical and occupational adaptations that can be applied to educational environments to improve performance for patients with special motor needs [22]. Recently, specific participation-focused models have been presented in relation to the physical rehabilitation of patients with cerebral palsy spastic motor type [23,24] based on the integration of multi-modal intervention approaches (physical, psychological, cognitive, and somatosensory). It is important to recognize, however, that the number of available studies in this domain is limited: only $5 \%$ of studies investigating intervention approaches for children with motor disability target community-based participation, with very limited evidence supporting the efficacy of participation-focused interventions [25].

Interestingly, age is a strong determining factor of physical activity for individuals with cerebral palsy spastic motor type, with marked decreases in physical activity levels as youth get older [26]. Furthermore, factors such as age, body mass index, and health comorbidities have been shown to serve as predictors for intervention outcomes [27-29]. Behavioral determinants of health (e.g., physical activity level, dietary choices, eating patterns, sleep patterns) are important moderators to consider for applied interventions in children with special motor needs but are often overlooked. These moderators should be weighed accordingly, with a focus on 
special education and adaptive physical education technologies that are capable of modifying health behaviors for individuals with special motor needs [30]. During the planning and development and behavior modification interventions, the Theoretical Domains Framework provides an empirically based structure encompassing 14 domains that is highly beneficial for facilitating theoretical approaches [31]. Paralleling that described above for adaptive recreational and leisure programs, some aspects of this theoretical framework relate to environmental (e.g., support, relationships, attitudes; products and technologies) or individual factors (e.g., cognitive ability, preferences, and social skills) while other facets relate specifically to behavior change (e.g., goals, intentions, reinforcement) [32]. Therefore, implementation and/or consideration of the theoretical domains framework during program development may promote physical activity and health outcomes in youth with special motor needs.

Adaptive techniques aimed at modifying behavior appropriate to a person's physical ability and improving motivation for individuals with physical disabilities to participate in recreational and leisure activities are currently based on explanations that special educators provide to patients and parents. In such cases, instructors explain alternative exercises, modified physical activity behaviors, and/or environmental accommodations that can be implemented using physical, somatosensory, and/or cognitive tools to enhance the performance of patients [33]. Although evidence is clear in terms of behavior change and modification, less is known about how these interventions indirectly impact physical activity levels in youth with special motor needs.

\section{Aim of the work}

The aim of this review is to determine the efficacy of behavioral (change) intervention techniques on physical activity levels for individuals with special motor needs across different (educational vs. leisure) participation domains.

\section{Methods}

\section{Research Strategy}

The search strategy used for the review was developed by a team of two authors (T.P. and H.M.) and focused on child and adolescent patients (up to 18 years of age) with cerebral palsy spastic-type. This diagnostic criterion was narrowed in an effort to standardize the patient category. To be included in this review, the selected articles had to include a description of motor dysfunction (spastic paresis), as well as all other necessary comanifestations, in the neurological diagnosis of cerebral palsy. For the purposes of this research, behavioral intervention is defined as the implementation of any rehabilitation strategy that aimed to improve the cognitive and/or physical outcomes of patients with special motor needs by addressing and encouraging behavior changes.

A pre-defined list of keywords indexed in article titles, keywords, and/or abstract text was established by this review team \{behavioral intervention, youth, cerebral palsy, physical activity and a systematic search was carried out across the MEDLINE, PubMed, Embase, Cochrane Library, EBSCO, and PEDro scientific/medical databases. EndNote bibliographic software (Clarivate Analytics, U.S.A.) was used to execute and manage the literature search; no publication date or publication status restrictions were imposed. To be included in this review, articles had to meet the following inclusion criteria:

1. full-text peer-reviewed journal article,

2. English language,

3. individual or group-based behavioral intervention conducted by a special educator or adaptive physical education specialist in a center, department, or school with an inclusive education program,

4. baseline (pre-intervention) and outcome (post-intervention) assessment available.

T.P. and H.M. independently screened titles and abstracts for relevant articles and extracted relevant information from each study. Any disagreement between the two authors was resolved by a third author (N.M.).

\section{Results}

A total of 148 records (142 online database search, 6 manual reference check) were identified, of which 61 duplicates were removed. Titles and abstracts for the remaining 87 articles were reviewed for keywords, resulting in 11 full-text articles selected for in-depth eligibility evaluation. After independent screening and consensus, 4 studies met our pre-defined eligibility criteria and were included in the systematic review (Figure 1). 


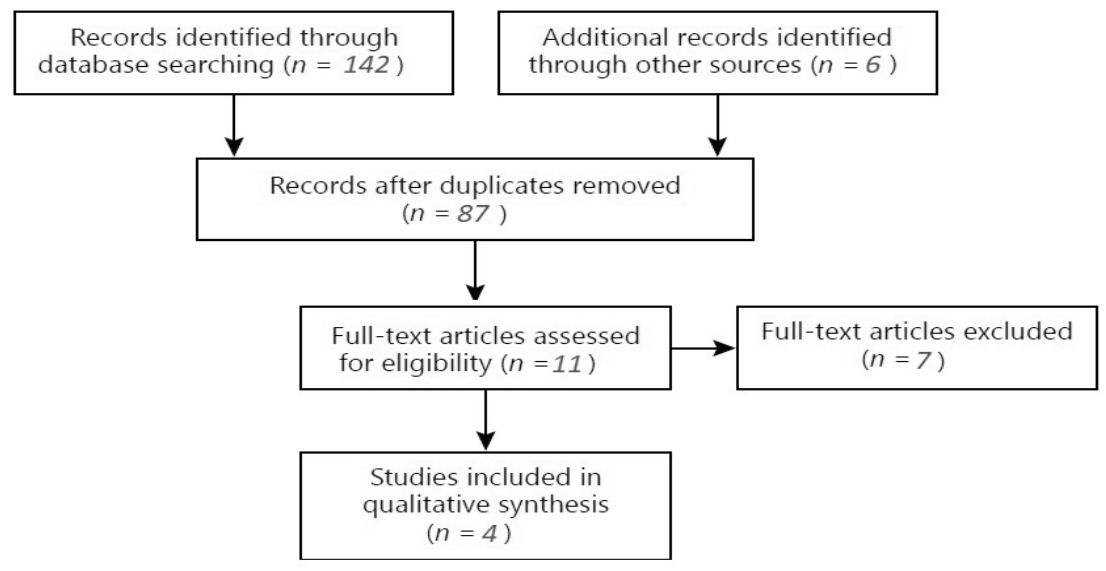

Figure 1. Flowchart depicting article retention and rejection across selection stages, in accordance with PRISMA guidelines

The four selected studies ( 3 randomized controlled trials, 1 case-control quasi-experimental design [34-36]) included a total of 173 youth (aged 8-19 years) diagnosed with cerebral palsy spastic motor type (55\% male, $45 \%$ female; Table 1).

\section{Intervention modalities and program descriptions}

Two internet-based interventions (Get Set and Mitii ${ }^{\mathrm{TM}}$ ), which children and adolescents completed at home, were evaluated. Specifically, Maher et al. [30] evaluated the Get Set intervention, an interactive Internet-based program based on social cognitive theory that integrates psychoeducation, quizzes, goal setting, self-reflection, and positive role-modelling via eight weekly (pre-designed) modules with e-mail or text messages reminders. Thereafter, Mitchell et al. [26] used the "Move it to improve it" (Mitii ${ }^{\mathrm{TM}}$ ) multi-modal therapy program which incorporates upper limb physical rehabilitation and cognitive training.

The other two studies (both published in 2015) focused on in-person interventions which could beimplemented at home and/or in the community. Law et al. [35] published an empirical evaluation of three leisure-oriented participation goals identified by the Canadian Occupational Performance Measure. Alternatively, a battery of fundamental movement skills (FMS) with skill-specific practice of two locomotor (run, jump) and three objectcontrol (kick, throw, and catch) actions were implemented and evaluated by Capio and colleagues [34].

\section{Outcomes}

Four different outcome measures were reported across studies (Table 1): moderate to vigorous physical activity (MVPA) [26,30,34], number of strides per day [26], sedentary activity time [26], and PA performance [35]. MVPA was typically measured in average minutes per day [26,30], although percentage of time observed [34] and average minutes per week [30] were also assessed. Mitchell et al. [26] was the only study to quantify time spent engaging in sedentary activities. The duration of interventional programs was from four to twenty weeks. The overall number of participants in these studies was 92 and the largest study group of participants $(n=50)$ was involved in the study by Law et al. [35] with the longest period of intervention. However, in all selected studies statistically non-significant differences were observed when comparing the interventional group data with the control groups or with the initial assessment data.

\section{Discussion}

The purpose of this review was to evaluate the efficacy of behavioral interventions on physical activity outcomes in children and adolescents with cerebral palsy (spastic-type) and to inform future research and rehabilitation options for youth with special motor needs. This process resulted in the identification of four studies [26,30,34,35] for which physical activity outcomes were measured during behavioral intervention evaluations. The developed inclusion criteria in this study aimed to select patients with the same type of neurological condition and motor limitations. The selection process revealed studies with the same category 


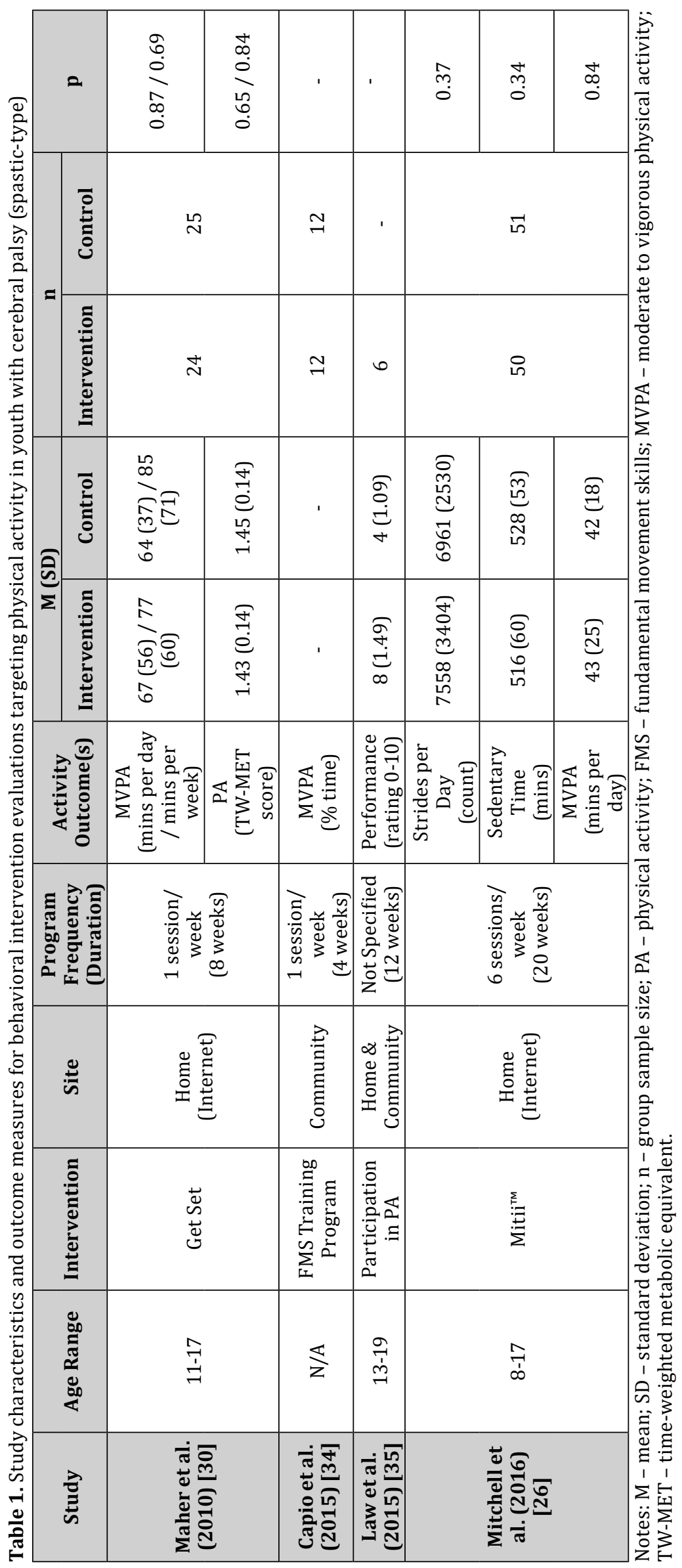


of CP patients assessing the same outcome. This small number of studies is not sufficient to warrant systematic review of the literature but provides valuable first steps to the population scope. Overall, physical activity levels were not statistically different between intervention and control groups ( $p s>.05)$, although youth with cerebral palsy made marginally more strides per day [26] and had slightly higher PA participation ratings [35] following behavioral intervention programs. Most of the included studies had primary aims to increase some elements of physical capacity.

It is interesting to note that similar patterns were observed across training modalities, irrespective of their target training behaviors or nature of delivery (Internet-based vs. in-person). Most studies also placed a heavy focus on physical capacity, which is consistent with physical capacity being an important predictive factor in a person's level of habitual physical activity [37-40].

The level of PA participation in different domains varies according to intensity and type of the participation, as well as individual factors (age, sex, BMI, lean body mass, etc.) for children with motor/physical disabilities other than cerebral palsy [41]. Cerebral palsy is a non-progressive dysfunction, while a group of congenital conditions result in progressive damage of the developing brain (maple syrup urine disease, organic acidurias, urea cycle disorders, nonketotic hyperglycinemia, etc.). At any age, when there is any deviation from the typical pattern of CP, with significant loss of previous physical and cognitive skills or decline in speech and vision, then an alternative diagnosis should be sought. Therefore, the assessment of participation is a rather difficult task [42]. The intervention methods overviewed here could be incorporated into physical rehabilitation programs for youth with special motor needs and, together with other physical modalities, have the potential to improve physical capacity.

There were limitations to the interpretation of the results reflected in this review. First and foremost, this review restricted the target population to cerebral palsy (spastic-type), rather than implementing a broader search (e.g., motor disability, special motor needs). This restrictive selection was implemented to target a standardized classification of participants with similar level of physical capacities and presentations. Although we were limited by the number of studies identified and thus restricting our ability to implement a more systematic review, we believe narrowing the diagnostic criteria increases interpretation reliability. It is also worth noting that not all studies included a comparator (control) condition, thereby making limiting group comparisons and interpretations of community-based intervention programs.

\section{Conclusions}

This review reveals no statistically significant effects of behavior change interventions on increasing the physical activity of patients with cerebral palsy (spastic-type) relative to comparative groups across four empirical studies. There is a need for additional research directly investigating the impact of cognitive and behavioral interventions on physical activity and motor capacity in youth with special needs. In particular, investigations would benefit from large sample sizes, multiple diagnostic groups, and/or broader diagnosis classifications (for improved generalizability).

\section{Disclosures and acknowledgements}

The authors declare no potential conflicts of interest with respect to the research, authorship, and/or publication of this article. This work was funded by the authors.

\section{References:}

1. Caspersen CJ, Powell KE, Christenson GM. Physical activity, exercise, and physical fitness: definitions and distinctions for health-related research. Public Health Rep. 1985; 100: 126-131.

2. Hielkema T, Hamer EG, Boxum AG, La Bastide-Van Gemert S, Dirks T, Reinders-Messelink HA, et al. LEARN2MOVE 0-2 years, a randomized early intervention trial for infants at very high risk of cerebral palsy: neuromotor, cognitive, and behavioral outcome. Disabil Rehabil. 2020; 42(26): 3752-3761. https://doi.org/10.1080/09638288.2019.1610508

3. Pate RR, O’Neill JR, Lobelo F. The evolving definition of “sedentary”. Exerc Sport Sci Rev. 2008; 36(4): 173178. https://doi.org/10.1097/JES.0b013e3181877d1a

4. Avagyan A, Mkrtchyan H, Shafa FA, Mathew JA, Petrosyan T. Effectiveness and determinant variables of augmentative and alternative communication interventions in cerebral palsy patients with communication deficit: a systematic review. Codas. 2021; 33(5): e20200244. https://doi.org/10.1590/23171782/20202020244 
5. Bratteby Tollerz LU, Forslund AH, Olsson RM, Lidstrom H, Holmback U. Children with cerebral palsy do not achieve healthy physical activity levels. Acta Paediatr. 2015; 104(11): 1125-1129. https://doi.org/10.1111/ apa.13141

6. Keawutan P, Bell KL, Oftedal S, Davies PSW, Ware RS, Boyd RN. Quality of life and habitual physical activity in children with cerebral palsy aged 5 years: a cross-sectional study. Res Dev Disabil. 2018; 74: $139-145$. https://doi.org/10.1016/j.ridd.2018.01.008

7. Mitchell LE, Ziviani J, Boyd RN. Habitual physical activity of independently ambulant children and adolescents with cerebral palsy: are they doing enough?. Phys Ther. 2015; 95(2): 202-211. https://doi.org/10.2522/ ptj. 20140031

8. Jonsson U, Eek MN, Sunnerhagen KS, Himmelmann K. Cerebral palsy prevalence, subtypes, and associated impairments: a population-based comparison study of adults and children. Dev Med Child Neurol. 2019; 61(10): 1162-1167. http://dx.doi.org/10.1111/dmcn.14229

9. Rosenbaum P, Paneth N, Leviton A, Goldstein M, Bax M, Damiano D, et al. A report: the definition and classification of cerebral palsy. Dev Med Child Neurol Suppl. 2007; 109: 8-14.

10. Avagyan A, Mkrtchyan H, Petrosyan T. Rare neurological diseases in children: current paradigm of communicational interventions and inclusion. Psycholinguistics. 2018; 24(1): 11-27. https://doi.org/10.31470/2309-1797-2018-24-1-11-26

11. Law M, Petrenchik T, King G, Hurley P. Perceived environmental barriers to recreational, community, and school participation for children and youth with physical disabilities. Arch Phys Med Rehabil. 2007; 88(12): 1636-1642. https://doi.org/10.1016/j.apmr.2007.07.035

12. Anaby D, Hand C, Bradley L, DiRezze B, Forhan M, DiGiacomo A, et al. The effect of the environment on participation of children and youth with disabilities: a scoping review. Disabil Rehabil. 2013; 35(19): 15891598. https://doi.org/10.3109/09638288.2012.748840

13. Bedell G, Coster W, Law M, Liljenquist K, Kao Y-C, Teplicky R, et al. Community participation, supports, and barriers of school-age children with and without disabilities. Arch Phys Med Rehabil. 2013; 94(2): 315-323. https://doi.org/10.1016/j.apmr.2012.09.024

14. Rosenberg L, Bart O, Ratzon N, Jarus T. Personal and environmental factors predict participation of children with and without mild developmental disabilities. J Child Fam Stud. 2013; 22: 658-671.

15. Heah T, Case T, McGuire B, Law M. Successful participation: the lived experience among children with disabilities. Can J Occup Ther. 2007; 74(1): 38-47. https://doi.org/10.2182/cjot.06.10

16. Whiteneck G, Dijkers MP. Difficult to measure constructs: conceptual and methodological issues concerning participation and environmental factors. Arch Phys Med Rehabil. 2009; 90(11): S22-35. https://doi.org/10.1016/j.apmr.2009.06.009

17. Van Wely L, Becher JG, Balemans ACJ, Dallmeijer AJ. Ambulatory activity of children with cerebral palsy: which characteristics are important?. Dev Med Child Neurol. 2012; 54(5): 436-442. https://doi.org/10.1111/ j.1469-8749.2012.04251.x

18. Horwood L, Li P, Mok E, Oskoui M, Shevell M, Constantin E. Behavioral difficulties, sleep problems, and nighttime pain in children with cerebral palsy. Res Dev Disabil. 2019; 95: 103500. https://doi.org/10.1016/j. ridd.2019.103500

19. Shikako-Thomas K, Majnemer A, Law M, Lach L. Determinants of participation in leisure activities in children and youth with cerebral palsy: systematic review. Phys Occup Ther Pediatr. 2008; 28(2): $155-169$. https://doi.org/10.1080/01942630802031834

20. Bult MK, Verschuren O, Jongmans MJ, Lindeman E, Ketelaar M. What influences participation in leisure activities of children and youth with physical disabilities? A systematic review. Res Dev Disabil. 2011; 32(5): 1521-1529. https://doi.org/10.1016/j.ridd.2011.01.045

21. Långh U, Perry A, Eikeseth S, Bölte S. Quality of early intensive behavioral intervention as a predictor of children's outcome. Behav Modif. 2020; 45(6): 911-928. https://doi.org/10.1177/0145445520923998

22. Carroll KL, Leiser J, Paisley TS. Cerebral palsy: physical activity and sport. Curr Sports Med Rep. 2006; 5: 319-322. https://doi.org/10.1007/s11932-006-0060-x

23. Novak I, McIntyre S, Morgan C, Campbell L, Dark L, Morton N, et al. A systematic review of interventions for children with cerebral palsy: state of the evidence. Dev Med Child Neurol. 2013; 55(10): 885-910. https://doi.org/10.1111/dmcn.12246

24. Baldwin P, King G, Evans J, McDougall S, Tucker MA, Servais M. Solution-focused coaching in pediatric rehabilitation: an integrated model for practice. Phys Occup Ther Pediatr. 2013; 33(4): $467-483$. https://doi.org/10.3109/01942638.2013.784718 
25. Palisano RJ, Chiarello LA, King GA, Novak I, Stoner T, Fiss A. Participation-based therapy for children with physical disabilities. Disabil Rehabil. 2012; 34(12): 1041-1052. https://doi.org/10.3109/09638288.2011. 628740

26. Mitchell LE, Ziviani J, Boyd RN. Habitual physical activity of independently ambulant children and adolescents with cerebral palsy: are they doing enough?. Phys Ther. 2015; 95(2): 202-211. https://doi.org/10.2522/ ptj.20140031

27. van Wely L, van Gorp M, Tan SS, van Meeteren J, Roebroeck ME, Dallmeijer AJ. Teenage predictors of participation of adults with cerebral palsy in domestic life and interpersonal relationships: a 13-year followup study. Res Dev Disabil. 2020; 96: 103510.

28. Rethwilm R, Böhm H, Haase M, Perchthaler D, Dussa CU, Federolf P. Dynamic stability in cerebral palsy during walking and running: Predictors and regulation strategies. Gait Posture. 2021; 84: 329-334. https://doi.org/10.1016/j.gaitpost.2020.12.031

29. Keeratisiroj O, Thawinchai N, Siritaratiwat W, Buntragulpoontawee M, Pratoomsoot C. Prognostic predictors for ambulation in children with cerebral palsy: a systematic review and meta-analysis of observational studies. Disabil Rehabil. 2018; 40(2): 135-143. https://doi.org/10.1080/09638288.2016.1250119

30. Maher CA, Williams MT, Olds T, Lane AE. An internet-based physical activity intervention for adolescents with cerebral palsy: a randomized controlled trial. Dev Med Child Neurol. 2010; 52(5): 448-455. https://doi.org/10.1111/j.1469-8749.2009.03609.x

31. Michie S, Johnston M, Abraham C, Lawton R, Parker D, Walker A. Making psychological theory useful for implementing evidence based practice: a consensus approach. Qual Saf Health Care. 2005; 14(1): 26-33. https://doi.org/10.1136/qshc.2004.011155

32. Cane J, O'Connor D, Michie S. Validation of the theoretical domains framework for use in behaviour change and implementation research. Implement Sci. 2012; 7: 37. https://doi.org/10.1186/1748-5908-7-37

33. Teixeira P, Carraca E, Markland D, Silva M, Ryan R. Exercise, physical activity, and self-determination theory: a systematic review. Int J Behav Nutr Phys. 2012; 9: 78. https://doi.org/10.1186/1479-5868-9-78

34. Capio CM, Sit CHP, Eguia KF, Abernethy B, Masters RS. Fundamental movement skills training to promote physical activity in children with and without disability: a pilot study. J Sport Health Sci. 2019; 4(3): $235-243$. https://doi.org/10.1016/j.jshs.2014.08.001

35. Law M, Anaby D, Imms C, Teplicky R, Turner L. Improving the participation of youth with physical disabilities in community activities: an interrupted time series design. Aust Occup Ther J. 2015; 62(2): 105-115. https://doi.org/10.1111/1440-1630.12177

36. Keawutan P, Bell K, Davies PSW, Boyd RN. Systematic review of the relationship between habitual physical activity and motor capacity in children with cerebral palsy. Res Dev Disabil. 2014; 35(6): 1301-1309. https://doi.org/10.1016/j.ridd.2014.03.028

37. Brunjes DL, Kennel PJ, Christian Schulze P. Exercise capacity, physical activity, and morbidity. Heart Fail Rev. 2017; 22(2): 133-139. https://doi.org/10.1007/s10741-016-9592-1

38. Tomás MT, Galán-Mercant A, Carnero EA, Fernandes B. Functional capacity and levels of physical activity in aging: a 3-year follow-up. Front Med (Lausanne). 2018; 4: 244. https://doi.org/10.3389/fmed.2017.00244

39. Barbosa DG, Andrade RD, Pelegrini A, Felden ÉP. Rating of perceived capacity: a proposal to predict adequate levels of physical activity in visually impaired individuals. J Sports Med Phys Fitness. 2019; 59(2): $274-282$. https://doi.org/10.23736/S0022-4707.17.08070-7

40. Cordova-Rivera L, Gibson PG, Gardiner PA, Powell H, McDonald VM. Physical activity and exercise capacity in severe asthma: key clinical associations. J Allergy Clin Immunol Pract. 2018; 6(3): 814-822. https://doi.org/10.1016/j.jaip.2017.09.022

41. Shikako-Thomas K, Kolehmainen N, Ketelaar M, Bult M, Law M. Promoting leisure participation as part of health and well-being in children and youth with cerebral palsy. J Child Neurol. 2014; 29(8): 1125-1133. https://doi.org/10.1177/0883073814533422

42. Coster W, Khetani MA. Measuring participation of children with disabilities: issues and challenges. Disabil Rehabil. 2008; 30(8): 639-648. https://doi.org/10.1080/09638280701400375 